\title{
MAIS UMA \\ META ATINGIDA
}

Mais uma meta foi atingida pela FEBRASGO ! Com o grande apoio da diretoria da Federação, as Comissões de Hipertensão na Gravidez e Perinatologia, exemplificando o trabalho desenvolvido pelas Comissões Especializadas, captaram o Congresso Mundial da Sociedade Internacional para o Estudo da Hipertensão na Gravidez. O evento irá acontecer durante o mês de outubro de 2004 no Rio de Janeiro, e contará com a presença de colegas brasileiros e de todas as partes do mundo na discussão de diversos aspectos da hipertensão na gravidez. O envolvimento politico com os mais diversos segmentos do Sistema Oficial de Saúde do país permitirá que um conjunto de propostas possa ser divulgado após o evento, com a finalidade de controlar a maior causa de morte materna em nosso país. A FEBRASGO estará a frente desta atitude, servindo como interlocutora deste processo.

Todos os Serviços de Obstetrícia serão convocados para participar. Gostaríamos que as sessões de Temas Livres tivessem a participação de muitos colegas. Os próximos quatro anos são suficientes para que uma série de pesquisas básicas, ensaios clínicos ou relato de casuísticas possam ser apresentadas. Nossos sócios serão motivados para que estejam conosco no Rio de Janeiro durante os cinco dias de evento. Um diálogo com os maiores pesquisadores internacionais deverá ser uma tônica que será incentivada pela Comissão Organizadora.

Lembre-se que todo o esforço despendido nos últimos quatro anos, e a mobilização dos próximos quatro, serão em vão sem sua presença. Coloque em sua agenda que em outubro de 2004, tentaremos em conjunto reverter uma vergonha nacional: as altas taxas de mortalidade materna. E novamente a FEBRASGO estará junto desta conquista.

\section{A Diretoria}

